Research Article

\title{
Serum Adiponectin Level is Lower in Patients with Endometriotic Cyst
}

\section{Tingkat Adiponektin Serum Lebih Rendah pada Pasien dengan Kista Endometriosis}

\author{
Fahdiansyah, Ruswana Anwar, Setyorini Irianti \\ Department of Obstetrics and Gynecology \\ Faculty of Medicine University of Padjadjaran/ \\ Dr. Hasan Sadikin Hospital \\ Bandung
}

\begin{abstract}
Objectives: To analyse the difference of serum adiponectin level between patients with endometriotic cyst and those with non-endometriotic cyst, and its difference between endometriosis stages.

Methods: This is a cross-sectional comparative analytical study involving 25 women with endometriotic cyst and 25 women with nonendometriotic cyst, which had undergone laparoscopy or laparotomy surgery. Blood samples were withdrawn and checked for serum adiponectin level in PRODIA laboratory in Jakarta. Serum adiponectin level of both groups were then measured and compared. The study was conducted in Dr. Hasan Sadikin Hospital in September- December 2012.
\end{abstract}

Results: Shows no significant difference in subjects' characteristic which are age $(p=0.994)$ and BMI $(p=0.267)$. There is a significant difference $(p<0.0001)$ between serum adiponectin level in endometriosis group (mean $=3.91 \pm 1.976)$ with level of which in nonendometriosis group (mean $=8.59 \pm 1.977$ ). There is no significant difference $(p=0.384)$ of serum adiponectin level between stage III endometriosis (mean $=4.24 \pm 1.8168)$ and stage IV endometriosis (mean $=3.54 \pm 2.1531)$.

Conclusion: Serum adiponectin level in patients with endometriotic cyst is significantly lower compared to level of which in patients with non-endometriotic cyst. There is no significant difference of serum adiponectin level between endometriosis stages.

[Indones J Obstet Gynecol 2013; 1-3: 119-23]

Keywords: adiponectin, endometriotic cyst, non-endometriotic cyst, endometriosis stage

\begin{abstract}
Abstrak
Tujuan: Untuk menganalisis perbedaan tingkat adiponektin serum antara pasien dengan kista endometriosis dan mereka dengan kista non-endometriosis, dan perbedaannya antara tahap endometriosis.

Metode: Penelitian ini merupakan studi analitik potong lintang komparatifyang melibatkan 25 wanita dengan kista endometriosis dan 25 wanita dengan kista non-endometriosis, yang telah menjalani laparoskopi atau operasi laparotomi. Sampel darah diambil dan diperiksa kadar adiponektin serum di laboratorium PRODIA di Jakarta. Tingkat adiponektin serum dari kedua kelompok kemudian diukur dan dibandingkan. Penelitian dilakukan di Rumah Sakit Dr. Hasan Sadikin pada bulan September-Desember 2012.
\end{abstract}

Hasil: Tidak terdapat perbedaan yang signifikan dalam karakteristik subjek yaitu usia $(p=0,994)$ dan BMI $(p=0,267)$. Ada perbedaan yang signifikan $(p<0,0001)$ antara kadar adiponektin serum pada kelompok endometriosis (mean $=3,91 \pm 1,976$ ) dengan kelompok nonendometriosis (rata-rata $=8,59 \pm 1,977$ ). Tidak ada perbedaan yang signifikan $(p=0,384)$ tingkat adiponektin serum antara stadium III endometriosis (mean $=4,24 \pm 1,8168$ ) dan stadium IV endometriosis (mean = 3,54 $\pm 2,1531$ ).

Kesimpulan: Tingkat adiponektin serum pada pasien dengan kista endometriosis secara signifikan lebih rendah dibandingkan dengan tingkat yang pada pasien dengan kista non-endometriosis. Tidak ada perbedaan yang signifikan tingkat serum adiponektin antara tahap endometriosis.

[Maj Obstet Ginekol Indones 2013; 1-3: 119-23]

Kata kunci: adiponektin, kista endometriosis, kista non-endometriosis, tahap endometriosis

Correspondence: Fahdiansyah. Department of Obstetrics and Gynecology. Faculty of Medicine University of Padjadjaran, Bandung. Telephone: 022-70835010. Email: ukupf@yahoo.co.id

\section{INTRODUCTION}

Endometriosis is a benign gynecological illness, which recently is being concerned by experts. In both developed and developing countries, many studies have been conducted about endometriosis. However, until now, its etiology and pathogenesis have not been clearly understood. Endometriosis is defined as endometrium-like tissue found outside uterus, especially in ovaries and pelvic cavity, which causes a chronic inflammatory reaction. Endometriosis is found in about $10 \%$ of women in reproductive age. Beside affect the woman's reproductive health, the clinical manifestations of en- dometriosis also affect the physical, mental, and social health. ${ }^{1}$

Incidence of endometriosis is not exactly known, as endometriosis is often left misdiagnosed or undiagnosed. A study conducted in Mayo clinic few years ago found endometriosis in about $50 \%$ of women who had undergone surgery in pelvic area, without mentioning the indications of the procedures. ${ }^{1,2}$

Many theories are proposed about pathogenesis of endometriosis. Recently it is believed that regurgitation of menstrual blood is the most common 
etiology of endometriosis, as the tubouterine muscle in endometriosis is weakened, which allows endometrial cells to spread into peritoneal cavity. Endometriosis is an estrogen-dependent illness, where estrogen plays an important part in endometriosis development. This can be seen in the way that endometriosis does not occur before menarche and very rarely does in women with anovulatory women. Even though endometriosis could occur in postmenopausal women, this is associated with the high level of estrogen due to obesity or estrogen therapy. ${ }^{1,3}$

Non-endometriotic cyst mentioned in this study is the ovarian cyst beside endometriosis, it is a sac containing fluid or semisolid material which grows within the ovary. Etiology of the non-endometriotic cyst is disruption of hormone production in hypothalamus, hypophysis, or ovaries. Excessive secretion of estrogen follows these kind of cysts. Based on the formation process, the cysts are divided into non-neoplastic cyst and neoplastic cyst. ${ }^{4}$

Adiponectin is an adipocyte-specific protein (adipocytokine) circulating in blood, found in high level. Beside anti-diabetic effect, adiponectin also has pleiotropic effects, such as anti-inflammatory, anti-angiogenic, and anti-atherosclerotic. ${ }^{5-7}$

Adiponectin has been proven to be expressed by endometrial tissue also, in much lower level than its circulating level, and the level are insignificantly different along menstrual cycle. Adiponectin receptors, AdipoR1 and AdipoR2, are also found in endometrial tissue in varied expression along the menstrual cycle, being highest in the middle of secretion phase. ${ }^{7,8}$

Takemura, et al. in 2005 reported that serum adiponectin level in women with endometriosis is significantly lower than level of which in women without endometriosis. It is not known whether that was the cause or effect of endometriosis. ${ }^{8}$

Until now, no data shows the association between adiponectin level and endometriosis incidence in Indonesia. Based on the description mentioned above, a question is formulated; whether or not adiponectin level differs in Indonesian women with and without endometriotic cyst.

Most of our people reject to undergo diagnostic laparoscopy, the gold standard diagnostic examination. Surgery, even the minor ones, are still considered terrifying, painful, risky, and costs a lot, so that many cases of endometriosis are ignored or not properly managed because they were undiagnosed. While on the other hand, the illness develops further, causing chronic pelvic pain, organ distortion, and infertility. 2,3,9

Understanding this situation, a question is formulated about the role of adiponectin in pathogenesis of endometriotic cyst. This is expected to open our insight wider about factors involved in pathogenesis of endometriosis.

Based on the pathogenesis concepts developing nowadays, we are interested in learning about the role of adiponectin in endometriotic cyst development, by analyzing serum adiponectin level molecular-defected endometriosis patients. Studies conducted in some centres found decline of serum adiponectin level. However, none of them had stated that the declined serum adiponectin level has a role in endometriosis pathogenesis or in predicting endometriosis recurrence.

From the description above, the topic of this study can be defined:

Endometriosis is an illness of which etiopathogenesis is not yet understood. Endometriosis is believed to be estrogen-dependent, where estrogen has an important part in the development of endometriosis. The increase of estrogen level enhances the activity of endometriosis. This increase of estrogen is caused by declined synthesis of the protein which binds estrogen (SHBG) by liver. This liver disorder is caused by insulin resistance by low uptake of glucose in circulation. These processes are preceded by low adiponectin level. Non-endometriotic cyst originated not from endometrial tissue. The increase of estrogen does not affect its development, therefore neither does adiponectin. The level of adiponectin is believed to explain the development and etiopathogenesis of endometriosis. Thus, analyzing adiponectin level in patients with endometriotic cyst and comparing it with the level of which in patients with non-endometriotic cyst is expected to prove the role of adiponectin in pathogenesis of endometriotic cyst. Whether there was difference of adiponectin level between patients with endo-metriotic cyst and non-endometriotic cyst would be reported in this study.

\section{METHOD}

This is a cross-sectional comparative analytical study involving 50 patients presented to gynecology polyclinic and fertility-endocrinology-repro- 
duction polyclinic of Dr. Hasan Sadikin Hospital, Bandung in September-December 2012. There were 25 subjects for each endometriotic cyst and non-endometriotic cyst group. Patients would undergo laparotomy or laparoscopy surgery, and blood sample would be taken. Serum adiponectin level of the samples was compared between the endometriotic cyst group with the non-endometriotic cyst, and between the endometriosis stages by American Society of Reproductive Medicine (rASRM).

For categorical data, the statistical analysis performed was chi-square test for $2 \times 2$ table and Kolmogorov Smirnov test for 2x3 table. For numerical data, such as level of adiponectin, Shapiro-Wilk normality test was performed before the statistical analysis. Then both groups of subjects were compared with unpaired t-test for normally-distributed data and Mann-Whitney test for data which were not normally-distributed. $\mathrm{P}$ value $<0.05$ reflects significant result.

Statistical analysis was performed with SPSS version 17.0 for Windows, with confidential level of $95 \%$ for $p$ value $<0.05$.

\section{RESULT}

The result of this study would be reported as characteristics of subjects, serum adiponectin level, and the difference of serum adiponectin level in patients with endometriotic cyst compared to nonendometriotic cyst. Characteristic of the subjects is shown in Table 1.

Table 1. Comparison of Characteristic of Subjects in Both Groups.

\begin{tabular}{cccc}
\hline \hline & \multicolumn{2}{c}{ Group } & \\
\cline { 2 - 3 } Characteristic & $\begin{array}{c}\text { Endometriotic } \\
\text { Cyst } \\
\mathbf{n = 2 5}(\%)\end{array}$ & $\begin{array}{c}\text { Non-Endome- } \\
\text { triotic Cyst } \\
\mathbf{n = 2 5} \text { (\%) }\end{array}$ & Significance \\
\hline Age (years old) & & & $\mathrm{p}=0.994^{*}$ \\
$\bullet<20$ & $1(33.3 \%)$ & $2(66.6 \%)$ & \\
- $20-35$ & $19(47.5 \%)$ & $21(52.5 \%)$ & \\
- $>35$ & $5(71.2 \%)$ & $2(28.6 \%)$ & \\
BMI Mean \pm SD & $23.48 \pm 1.90481$ & $24.20 \pm 2.56843$ & $\mathrm{p}=0.267^{* *}$ \\
\hline
\end{tabular}

Note: * Kolmogorov-Smirnov test, $p>0.05$ (not significant), ** unpaired $t$-test, $p>0.05$ (not significant)

As shown in Table 1, 50 subjects are differentiated by age and BMI. The age of the subjects as categorical data, are compared with Kolmogorov-
Smirnov test. While the BMI, which are not-normally-distributed numerical data, are compared with unpaired t-test. Statistical analysis with confidence level of $95 \%$ results in p value of $>0.05$, means that the age and BMI of both groups are considered similar. The homogeneity of the subjects allows them to be analyzed further.

Table 2. Comparison of Serum Adiponectin Level in Patients with Endometriotic Cyst and non-Endometriotic Cyst.

\begin{tabular}{lccc}
\hline \hline \multirow{2}{*}{$\begin{array}{c}\text { Serum } \\
\text { Level }\end{array}$} & \multicolumn{2}{c}{ Group } & \\
\cline { 2 - 3 } & $\begin{array}{c}\text { Endometriotic } \\
\text { Cyst (n=25) }\end{array}$ & $\begin{array}{c}\text { Non-endometriotic } \\
\text { Cyst (n=25) }\end{array}$ & Significance \\
\hline Mean & 3.91 & 8.59 & $\mathrm{p}<0.0001^{* *}$ \\
SD & 1.976 & 1.977 & \\
\hline \hline Note: ${ }^{* *}$ unpaired t-test, $p<0.05$ (significant) &
\end{tabular}

Table 2 shows that mean serum adiponectin level in patients with endometriotic cyst is lower than those with non-endometriotic cyst. The nonendometriotic cysts of the subjects were mucinous cyst $(n=8)$, mature teratoma $(n=7)$, hemorrhagic luteal cyst $(n=6)$, and follicle cyst $(n=4)$. Statistical analysis with confidence level of $95 \%$ results in $p$ value of $<0.05$ or significant result. This shows a significant difference of serum adiponectin level in both groups, where serum adiponectin level in patients with endometriotic cyst is significantly lower than those with non-endometriotic cyst.

Table 3. Comparison of Serum Adiponectin Level in Patients with Stage III and Stage IV Endometriotic Cyst.

\begin{tabular}{lccc}
\hline \hline \multirow{2}{*}{$\begin{array}{c}\text { Serum } \\
\text { Adiponectin } \\
\text { Level }\end{array}$} & $\begin{array}{c}\text { Stage III Endome- } \\
\text { triosis (n=13) }\end{array}$ & $\begin{array}{c}\text { Stage IV Endome- } \\
\text { Signi- } \\
\text { ficance }\end{array}$ \\
\cline { 2 - 3 } Rerata & 4.24 & 3.54 & $\mathrm{p}=0.384^{* *}$ \\
SD & 1.81 & 2.15 & \\
\hline \hline
\end{tabular}

Note: ${ }^{* *}$ unpaired t-test, $p>0.05$ (not significant)

Table 3 shows that mean serum adiponectin level in patients with stage III endometriosis is higher than those of stage IV endometriosis. Statistical analysis with confidence level of $95 \%$ results in $p$ value of $>0.05$, fails to prove any significant difference of serum adiponectin level between both groups. The serum adiponectin level in the group with stage III endometriosis is higher, but not significantly, than the level of which in the group with stage IV endometriosis. 


\section{DISCUSSION}

The characteristic of the subjects compared in this study are the age and BMI, as these variables were anticipated to be confounding factors in this study, while the characteristic of subjects ought to be homogeny so the study results would be valid. The statistical analysis of the characteristics results in $\mathrm{p}$ value of 0.994 for the age and 0.267 for the BMI, which means there is no significant difference of characteristic between the group with endometriotic cyst and those with non-endometriotic cyst.

A study conducted by Kadowaki T. results in negative correlation between adiponectin with body weight, body fat mass, and insulin level. Loss of body weight in obese individuals leads to increase of adiponectin level in plasma. On the other hand, the low level of plasma adiponectinis found in conditions related to insulin resistance, such as cardiovascular diseases. ${ }^{10}$

This study shows lower level of adiponectin in patients with endometriotic cyst compared to those with non-endometriotic cyst, with $\mathrm{p}$ value of $<0.0001(\mathrm{p}<0.05)$ which means that the difference is significant. This result is consistent with the report by Takemura. In which serum adiponectin level in women with endometriotic cyst is significantly lower than women without endometriosis. ${ }^{8}$

Estrogen is recognized to stimulate the development of endometriosis. The insulin resistance induced by low level of adiponectin is probably related with the low level of SHBG. In conditions of insulin resistance, high level of insulin is found in circulation. This blocks SHBG production in the liver, causing a potentiation effect to estrogen. Adiponectin also inhibit angiogenesis, both in vitro and in vivo. This explains how the low level of adiponectin did not inhibit angiogenesis, so endometriosis can occur.

Low circulating level of adiponectin is associated with increase of plasma insulin. The circulating insulin level is inversely proportional with the level of insulin-like growth factor-binding protein 1 (IGFBP-1) bound to insulin-like growth factor 1 (IGF-1), also reduces its biological effect. The low level of adiponectin enhances IGF-1 effect in stimulating the development of endometriosis. Peritoneal inflammation is involved in the pathogenesis of endometriosis. Various cytokines are found increased in serum and peritoneal fluid of women with endometriosis. Adiponectin is recognized to suppress the activity of macrophage. Besides, the circulating level of adiponectin is associated with proinflammatory condition related to endometriosis. Adiponectin also induces the phosphorylation of AMPK and suppresses secretion of IL-6, IL-8, and MCP-1 induced by IL-1 in the endometrial cell culture, so that adiponectin is expected to is involved in physiology and pathology of endometrium. The declined expression of adiponectin receptors in endometriosis might have a role in the pathophysiology of endometriosis. ${ }^{8}$

This study result shows that mean level of adiponectin in subjects with stage III endometriosis is higher than those of stage IV endometriosis. Statistical analysis performed with unpaired t-test with confidence level of $95 \%$ results in $p$ value of $0.384(p>0.05)$. Thus, there is no significant difference of adiponectin level in patients with stage III and stage IV endometriosis, even though the level of which in stage III endometriosis is higher than those of stage IV endometriosis.

This result is inconsistent with former study by Takemura, in which the adiponectin level in peritoneal fluid of women with endometriosis is significantly lower than those who did not have endometriosis. This might be caused by the slow turnover of adiponectin, relatively long half time of adiponectin, and the relatively higher level of adiponectin in the circulation. ${ }^{7,8}$

To increase the sensitivity of adiponectin level measurement in endometriosis, measurement of HMW level can be performed, as HMW molecular structure is has been recognized having bioactivity, unlike MMW and LMW structure which are still unknown. This also had been proven by Liu in subjects with metabolic syndrome, where HMW level is positively correlated with metabolic syndrome, while MMW (hexamer) and LMW (trimer) adiponectin does not and only correlates with the ideal body weight, consecutively. ${ }^{11}$

This study is consistent with former study stating that adiponectin level in serum of women with endometriotic cyst is significantly lower than those without endometriosis. ${ }^{8}$

This study is limited in some ways that some preexisting conditions such as hypertension or cardiovascular diseases, age, and obesity, might be influence the result as confounding factors. 


\section{CONCLUSION}

Serum adiponectin level in patients with endometriotic cyst is significantly lower compared to level of which in patients with non-endometriotic cyst. There is no significant difference of serum adiponectin level between endometriosis stages.

\section{REFERENCES}

1. Kennedy S, Bergqvist A, Chapron C, D'Hooghe T, Dunselman G, Greb R. ESHRE guideline for the diagnosis and treatment of endometriosis. Hum Reprod. 2005; 20(10): 2698-704.

2. Eskenazi B, Warner M. Epidemiology of Endometriosis. Obstet Gynecol Clin North Am. 1997; 24(2): 235-58.

3. Agic A, Xu H, Finas D, Banz C, Diedrich K, Hornung D. Is endometriosis associated with systemic subclincal inflammation? Gynecol Obstet Invest. 2006; 62: 139-47.

4. Speroff L, Fritz M. Clinical Gynecologic Endocrinology and Infertility. $7^{\text {th }}$ ed: Lippincott Williams and Wilkins; 2005.

5. Kadowaki T, Yamauchi T. Adiponectin and adiponectin receptors. Endocr Rev. 2005; 26(3): 439-51.
6. Diez J, Iglesias P. The role of the novel adipocyte-derived hormone adiponectin in human disease. Eur J Endocri. 2003; 148: 293-300.

7. Takemura Y OYYT, Kobayashi M, Harada M, Hirata T. Expression of adiponectin receptors and it possible implication in the human endometrium. Endocrinol Rev. 2006; 147(7): 3203-10.

8. Takemura Y, Osuga Y, Yamauchi T, Koga K, Harada M, Morimoto C. Serum adiponectin concentrations are decreased in women with endometriosis. Hum Reprod. 2005; 20(12): 3510-3.

9. Leyland N, Casper R, Laberge P, Singh SS. Endometriosis: Diagnosis and Management. J Obs Gynecol Can. 2010; 244: 1-26.

10. Kadowaki T, Yamauchi T, Kubota N, Hara K, Ueki K, Tobe $\mathrm{K}$. Adiponectin and adiponectin receptors in insulin resistance, diabetes and the metabolic syndrome. J Clin Invest. 2006; 116: 1784-92.

11. Liu Y, Retnakaran R, Hanley A, Tungtrongchitr R, Shaw C, Sweeney G. Total and hight molecular weight but not trimeric forms of adiponectin correlate with marker of the metabolic syndrome and liver injury in the subjects. J Clin Endocrinol Metab. 2007; 92(11): 313-8. 